\title{
SZABAD DIETANOL-AMIN-TARTALOM MEGHATÁROZÁSA
}

\section{DETERMINATION OF FREE DIETHANOLAMINE CONTENT}

\author{
Nagy Roland, ${ }^{1}$ Hartyányi Máté, ${ }^{2}$ Nagy Bianka, ${ }^{3}$ Varga Csilla ${ }^{4}$ \\ Pannon Egyetem, MOL- Ásványolaj- és Széntechnológiai Intézeti Tanszék, Veszprém, Magyarország \\ ${ }^{1}$ nroland@almos.uni-pannon.hu \\ ${ }^{2}$ mate.hartyanyi@gmail.com \\ ${ }^{3}$ nagy.bianka@mk.uni-pannon.hu \\ ${ }^{4}$ vcsilla@almos.uni-pannon.hu
}

\begin{abstract}
Quantification of alkanolamines is imperative for health and chemical safety risk reasons. A fast method that requires less equipment has been developed for the determination of free diethanolamine in different types of additives. Repeatability tests were carried out. The free diethanolamine content of commercially available additives has been determined. We have recommended industrial applicability.
\end{abstract}

Keywords: DEA, additives, method, development.

\section{Összefoglalás}

Az alkanol-aminok mennyiségének meghatározása egészségügyi és kémiai biztonsági kockázati okokból rendkívül fontos. Gyors és kisebb eszközigényü módszert dolgoztunk ki, mellyel a szabad dietanol-amin különböző adalékokban meghatározható. Ismételhetőségi vizsgálatokat végeztünk. Kereskedelmi forgalomban is kapható adalékok szabad dietanol-amin tartalmát határoztuk meg. Ajánlást tettünk ipari alkalmazhatóságra.

Kulcsszavak: DEA, adalék, módszerfejlesztés.

\section{Bevezetés}

Napjainkban elengedhetetlen a hatékony módszer az alkanol, és az alkil-aminok mennyiségének meghatározására, azok lehetséges egészségügyi és kémiai biztonsági kockázatai miatt. A dietil-, illetve a trietil-amint reagensként használják fel számos gyógyszerészeti összetevő, például az oxibutinin-hidroklorid vagy a trazodon-hidroklorid gyártási folyamatában [1]. A kozmetikumokban és testápolási termékekben megtalálható dietanol-amin mennyisége korlátozott, mivel a dietanol-amin-maradványok reakcióba léphetnek más speciális összetevőkkel, melynek eredményeképpen rendkívül erős karcinogén tulajdonsággal rendelkező nitrozo-dietanol-amin képződik [2]. Ebből adódóan az említett komponensek kvalitatív és kvantitatív meghatározása nélkülöz- hetetlen feladat. Az alkanol-aminok elemzésére rendelkezésre álló módszerek közül agáz-kromatográfiát vagy a folyadék-kromatográfiát alkalmazó technikák kapják a legnagyobb figyelmet. A korszerübb eljárások a kromatográfiás elválasztást tömeg-spektroszkópiás módszerrel ötvözik. A kromatográfiás elválasztás és detektálás javításának érdekében az alkanol-aminok származékképzését valósítják meg, melynek célja az analit elemzésre alkalmasabb formába történő átalakítása [2]. A származékképzés legegyszerübb módja egy olyan reagens használata, mely képes reagálni az analitok jellegzetes csoportjával, és azzal „származékot” képezni. A folyadék-kromatográfiával végzett analitikai alkalmazásokra vonatkozóan a derivatizáció kétféle módon hajtható végre: vagy oszlop előtti vagy oszlop utáni derivatizációval (PCD) [3]. A dietanol-amin-tartalom meghatáro- 
zására gyors és egyszerű a GC-MS-módszer, azonban a megbízható mennyiségi meghatározáshoz a mintának minimum $1000 \mathrm{mg} / \mathrm{kg}$ DEA-tartalommal kell rendelkeznie [2]. A DEA (dietanol-amin) és TEA (trietanol-amin) kvantitatív meghatározásához a mintához történő nátrium-hidroxid hozzáadagolását követően dimetil-szulfoxidban szükséges feloldani. Mivel az oldatban ionos kötés nem lehetséges, a DEA ésa TEA könnyen kinyerhető és mennyiségileg meghatározható, gőztér-mintaadagoló gáz-kromatográfiás módszer alkalmazásával [1].

Szakirodalmi közleményeket áttekintve, DEA-tartalom meghatározására csak többlépcsős, műszeres analitikai módszer lehetséges. Célunk egyszerű, gyors és kis eszközigényű módszer kidolgozása.

\section{Felhasznált anyagok}

Méréseinkhez DEA és PEG (polietilén-glikol), illetve kókuszzsírsav reakciótermékeket használtunk fel.

1. táblázat. A felhasznált anyagok tulajdonságai

\begin{tabular}{|l|l|l|}
\hline & \multicolumn{1}{|c|}{ DEA } & \multicolumn{1}{c|}{ PEG-300 } \\
\hline Molekulatömeg $(\mathrm{g} / \mathrm{mol})$ & 105,14 & $285-315$ \\
\hline Forráspont $\left({ }^{\circ} \mathrm{C}\right)$ & 268 & $>220$ bomlik \\
\hline Dermedéspont $\left({ }^{\circ} \mathrm{C}\right)$ & 28 & -15 és -8 között \\
\hline Sürüség $\left(\mathrm{g} / \mathrm{cm}^{3}\right)$ & 1,09 & 1,125 \\
\hline
\end{tabular}

A DEA és PEG-300-at tulajdonságai alapján alkalmasnak találtuk a vizsgálatok elvégzésére.

2. táblázat. Zsírsav-DEA-reakciótermékek tulajdonságai

\begin{tabular}{|l|l|l|l|}
\hline & \multicolumn{1}{|c|}{ Coco-DEA } & \multicolumn{1}{|c|}{ Coco-DEA } & $\begin{array}{l}\text { Zsírsav } \\
\text { DEA }\end{array}$ \\
\hline Gyártó & $\begin{array}{l}\text { Alpha Chem- } \\
\text { ical }\end{array}$ & $\begin{array}{l}\text { Kelemen és } \\
\text { Társa }\end{array}$ & $\begin{array}{l}\text { (MOL } \\
\text { Lub Kft.) }\end{array}$ \\
\hline pH & $5,5-7,5$ & $5,6-7,5$ & $6-8$ \\
\hline szín & világos sárga & világos sárga & $\begin{array}{l}\text { világos } \\
\text { sárga }\end{array}$ \\
\hline $\begin{array}{l}\text { Szabad } \\
\text { zsírsav, w\% }\end{array}$ & max 1,5 & max 1,0 & max 1,0 \\
\hline $\begin{array}{l}\text { Vízben való } \\
\text { oldhatóság, } \\
\text { 20C-on }\end{array}$ & $\begin{array}{l}\text { teljes oldódás, } \\
\text { pH 9,0-10,5 }\end{array}$ & $\begin{array}{l}\text { teljes oldódás, } \\
\text { pH 9,0-10,5 }\end{array}$ & \\
\hline
\end{tabular}

A vizsgált zsírsav-DEA reakciótermékek tulajdonságai szűk tartományban mozogtak.

\section{Módszerkidolgozás}

Munkánk során egy új, egyszerű és gyors kísérleti módszer kidolgozását végeztük el, amelynek segítségével különböző adalékok, készítmények szabad amintartalmát lehet meghatározni. A módszer segítségével jellemezhető az alapanyagok konverziója. A szabad amintartalom ismeretében a készítmény minőségellenőrzése is szélesebb körü lehet [4]. A módszer kidolgozása során a ITM-40-006-jelü szabvány volt a kiindulópont [5].

\section{A vizsgálat végrehajtása}

- 1 g vizsgálandó anyag bemérése

- az elegy feloldása 10 ml metanolban

- 100 ml IPA/víz hozzáadása az oldathoz

- az így kapott elegy titrálása $0,1 \mathrm{M} \mathrm{HCl}$ oldattal

\section{1 liter IPA/víz készítése}

- 7,5 g káliumklorid bemérése

- a bemért káliumklorid feloldása $330 \mathrm{ml}$ desztillált vízben

-670 ml izopropil-alkohol hozzáadása az oldathoz

\section{Titrálás}

-az elegy Erlenmayer-lombikba történő bemérése

- egy csepp metilvörös indikátor hozzáadása

- az átcsapási szín megjelenéséig való titrálás

A szabad amintartalom meghatározásához alkalmazott egyenlet a következő:

$$
w t \%=\frac{V_{f} * f * K * C_{H C l}}{m}
$$

ahol:

$V_{f} \quad-$ a $0,1 \mathrm{M}$ sósav fogyása $\mathrm{cm}^{3}$-ben

$f \quad$ - a sósav faktora (értéke 1 , mivel dedikált sósavval titráltam)

$K$ - titer szám

$C_{H C l}$ - a sósav koncentrációja

$m$ - a bemért minta tömege g-ban.

Elvégeztük a módszer ismételhetőségének vizsgálatát, amelynek eredményeit a 3. táblázat tartalmazza.

Az ismételhetőségvizsgálatok (RSD-érték kisebb, mint 5\%) alapján megállapítottuk, hogy a kidolgozott módszer megbízhatóan ismételhető. Ezek alapján a módszerrel további vizsgálatokat végeztünk. 
3. táblázat. Ismételhetőségi vizsgálatok eredményei

\begin{tabular}{|l|c|}
\hline & $\begin{array}{c}\text { Szabad amin tarta- } \\
\text { lom }\end{array}$ \\
\hline Coco-DEA reakciótermék 1 & 14,2 \\
\hline Coco-DEA reakciótermék 2 & 14,1 \\
\hline Coco-DEA reakciótermék 3 & 14,1 \\
\hline Coco-DEA reakciótermék 4 & 13,9 \\
\hline Coco-DEA reakciótermék 5 & 14,0 \\
\hline Átlag & 14,1 \\
\hline Szórás & 0,14 \\
\hline RSD\% & 0,98 \\
\hline
\end{tabular}

\section{Eredmények}

A vizsgálatokat különböző arányú DEA/PEG 300 keverékének szabad amintartalmának meghatározásával kezdtük. A mérési eredményeket a 4. táblázat tartalmazza.

4. táblázat. Különböző DEA-tartalmú termékek vizsgálata

\begin{tabular}{|l|c|c|c|c|c|c|c|}
\hline \multicolumn{1}{|c|}{$\begin{array}{c}\text { Minta } \\
\text { sorszáma }\end{array}$} & $\mathbf{1 .}$ & $\mathbf{2 .}$ & $\mathbf{3 .}$ & $\mathbf{4 .}$ & $\mathbf{5 .}$ & $\mathbf{6 .}$ & $\mathbf{7 .}$ \\
\hline $\begin{array}{l}\text { Bemérés } \\
\text { alapján } \\
\text { DEA-tartalom } \\
\text { W\% }\end{array}$ & 1,00 & 5,20 & $\mathbf{9 , 9}$ & 15,10 & 20,15 & 25,05 & 50,10 \\
\hline $\begin{array}{l}\text { Titrimetriás } \\
\text { módszerrel } \\
\text { meghatáro- } \\
\text { zott DEA-tar- } \\
\text { talom w\% }\end{array}$ & 1,11 & 4,98 & 10,05 & 15,08 & 20,12 & 24,99 & 49,91 \\
\hline
\end{tabular}

Megállapítottuk, hogy az új módszerrel meghatározott, szabad DEA-tartalom a bemérési adatokkal jól korrelál, melyet az 1 . ábra szemléltet.

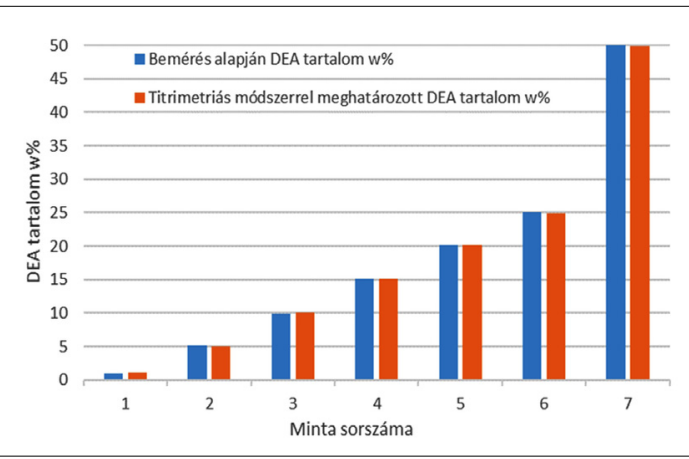

1. ábra. Különböző DEA-tartalmú termékek vizsgálata
A vizsgálatokat különböző gyártó által gyártott DEA-tartalmú termékek szabad amintartalmának meghatározásával folytattuk. A mérési eredményeket az 5. táblázat tartalmazza.

5. táblázat. Kereskedelmi tenzidek DEA-tartalma

\begin{tabular}{|c|c|c|}
\hline Minta jele & $\begin{array}{c}\text { Titrimetriás } \\
\text { módszerrel } \\
\text { meghatározott } \\
\text { DEA-tartalom } \\
\text { w\% }\end{array}$ & $\begin{array}{c}\text { Gyártó által } \\
\text { megadott } \\
\text { DEA-tartalom } \\
\text { w\% }\end{array}$ \\
\hline $\begin{array}{c}\text { Coco DEA } \\
\text { (Alpha Chemical) }\end{array}$ & 14,05 & 14,20 \\
\hline $\begin{array}{c}\text { Coco DEA } \\
\text { (Kelemen \& Társa } \\
\text { Kft.) }\end{array}$ & 12,80 & 12,80 \\
\hline $\begin{array}{c}\text { Zsírsav DEA } \\
\text { (MOL Lub Kft.) }\end{array}$ & 14,45 & 14,50 \\
\hline
\end{tabular}

Megállapítottuk, hogy az új módszerrel meghatározott szabad DEA-tartalom a gyártó által megadott adatokkal jól korrelál, melyet a 2 . ábra szemléltet.

Méréseink jól tükrözik, hogy a bemutatott módszerrel pontosan meghatározható a DEA-tartalom, mind beméréssel ellenőrizve, mind pedig a gyártó által megadott DEA-értékekhez viszonyítva.

\section{Következtetések}

Vizsgálataink során az alábbi megállapításokat nyertük:

- sikerült gyors, kis eszközigényü DEA-tartalom meghatározására alkalmas módszert kidolgozni,

- a módszer megbízhatósága adódott,

-a kidolgozott módszer alkalmas késztermékek DEA-tartalmának meghatározására.

A kidolgozott módszer egyszerüsége miatt a DEA-tartalmú készítmények gyártása során az üzem területén is alkalmazható.

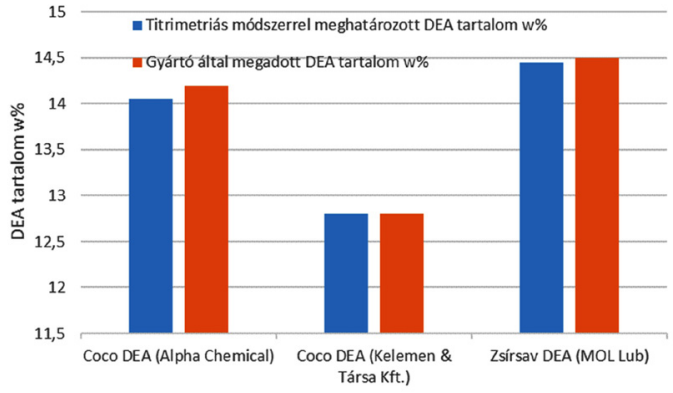

2. ábra. Különbözö gyártók DEA-tartalmú adalékoknak vizsgálata 


\section{Szakirodalomi hivatkozások}

[1] Ashish R. Deshpande, Ganesh Ramachandran, Ramesh S. Yamgar: Determination of diethylamine and triethylamine quantitatively using GC-headspace chromatography. Eurasian Journal of Analytical Chemistry, 7/1. (2012) 43-48.

[2] EN ISO 18818: Cosmetics, Analytical method, Detection and quantitative determination of Diethanolamine (DEA) by GC/MS, 2017.

[3] Zacharis C. K., Tzanavaras P. D.: Liquid Chromatography coupled to on-line post column deri- vatization for the determination of organic compounds: a review on instrumentation and chemistries, Analytica Chimica Acta, 798/10. (2013) 1-24, https://doi.org/10.1016/j.aca.2013.07.032

[4] Longman G. F. : The Analysis of Detergents and Detergent Products. First Edition. John Wiley \& Sons Ltd., 1975, 276-344.

[5] ITM-40-006. Free Amine in PIB-MALA Amine Dispersants: Potentiometric Titration Method. 2002 (szeptember 18.). 